\title{
Effect of Pulsed Electromagnetic Field Versus Aerobic Exercise on Primary Dysmenorrhea
}

\author{
MOHAMED A. AWAD, Ph.D.*; ASMAA M. ELBANDRAWY, Ph.D.*; AMIR A. GABR, M.D.** and \\ AYA H. ABD EL HAMID, M.Sc.**** \\ The Department of Physical Therapy for Women Health, Faculty of Physical Therapy, Cairo University*, \\ The Department of Obstetrics and Gynecology, Faculty of Medicine, Cairo University** and \\ The Department of Physical Therapy for Women Health, Faculty of Medicine, $6^{\text {th }}$ of October University***, Egypt
}

\begin{abstract}
Background: Dysmenorrhea is the most common gynecologic complaint among adolescent and young adult females, so the purpose of this study was to investigate the effect of pulsed electromagnetic field versus aerobic exercise on primary dysmenorrhea.
\end{abstract}

Aim of Study: This study was conducted to compare between the effect of pulsed electromagnetic field and aerobic exercise on primary dysmenorrhea.

Subjects and Methods: Forty girls diagnosed with primary dysmenorrhea participated in this study. They were selected randomly from Kasre El-Ainy University Hospital in Cairo. They had regular menstrual cycle. Their ages were ranged from 16-25 years. Their Body Mass Index (BMI) was ranged from $20-25 \mathrm{Kg} / \mathrm{m}$. All of them were virgins. Girls with irregular or infrequent menstrual cycles, pacemaker, hyperthyroidism, pelvic pathology and BMI $<25 \mathrm{Kg} / \mathrm{m}$ or $>20 \mathrm{Kg} / \mathrm{m}$ are excluded from the study.

Design: Design of this study was two group pre-test and post-test experimental design.

Methods: They were divided into two equal groups: Group A consisted of twenty girls and treated by pulsed electromagnetic field on the pelvic region, 3 times per week for four weeks. Group B consisted of twenty girls and treated by aerobic exercise, 3 times per week for four weeks.

Evaluation: Pain was evaluated by VAS, quality of life was assessed by short form survey (SF-12) and progesterone hormone was evaluated for both groups (A and $\mathrm{B})$ before and after treatment.

Results: Results found that; pre-treatment, there was no significant difference between both groups (A and B) in progesterone hormone, VAS and quality of life. While posttreatment, there was significant difference between both groups (A and $\mathrm{B}$ ) in progesterone hormone (more increase in group A), VAS (more decrease in group A) and quality of life (more increase in group A).

Correspondence to: Dr. Mohamed A. Awad, The Department of Physical Therapy for Women Health, Faculty of Physical Therapy, Cairo University
Conclusion: It can be concluded that pulsed electromagnetic field is more effective than aerobic exercise in treating primary dysmenorrhea.

Key Words: Primary dysmenorrhea - Pulsed electromagnetic field-Aerobic exercise.

\section{Introduction}

DYSMENORRHEA is the most common gynecologic complaint among adolescent and young adult females [1]. It is defined as the presence of painful cramps of uterine origin that occur during menstruation and represents one of the most common causes of pelvic pain and menstrual disorder [2]. A female's reproductive years are those between menarche (the first menstrual cycle) and menopause (cessation of menses for 12 consecutive months) $[3,4]$.

Primary dysmenorrhea is defined as painful menses in women with normal pelvic anatomy. It is characterized by abdominal pain beginning shortly before or at the onset of menses and lasting 1 to 3 days [5]. Primary dysmenorrhea occurs in up to $50 \%$ of menstruating females and causes significant disruption in quality of life [6].

Menstrual cramps are associated with nausea in $55 \%$, and with vomiting in $24 \%$ [7]. The severity of symptoms positively correlates with the onset of ovulatory cycles and with increased duration and amount of menstrual flow [8].

A physiological reason for dysmenorrhea is the production of uterine prostaglandins. During endometrial sloughing, endometrial cells release prostaglandins as menstruation begins [9].

Several approaches have been proposed for dysmenorrhea, including Non-Steroid Anti-Infla- 
mmatory Drugs (NSAIDs), oral contraceptives and vitamins [10].

Non-Steroidal Anti-Inflammatory Drugs (NSAIDs) inhibit the activity of cyclooxygenase-1 and-2 isoforms, leading to a reduction in prostaglandin production resulting in less vigorous contractions of the uterus and less discomfort [11].

Oral contraceptive prevents or lessens dysmenorrhea directly by limiting endometrial growth and reducing the amount of endometrial tissue available for prostaglandin production, and indirectly by inhibiting ovulation and subsequent progesterone secretion. A decrease in menstrual fluid and inflammatory mediators during oral contraceptive use are observed [12].

Pulsed Electromagnetic Fields (PEMF) are now used as one of the efficient modalities in the field of physical therapy for the treatment of many pathological conditions. It exhibits vasodilatation, analgesic action, anti-inflammatory action and anti-edematous activity. Electromagnetic therapy carries the promise to heal numerous health problems even where conventional medicine has failed. Magneto-therapy provides a non-invasive, safe and easy method to directly treat the site of injury, the source of pain and inflammation, and a variety of diseases and pathologies. Pulsed Electromagnetic fields (PEMF) are one important modality in magneto-therapy [13,14].

The magnetic therapy has begun immediately after the World War II. FDA allowed the use of the Pulsed Radiofrequency Electromagnetic Field (PRF) for the treatment of pain and edema in superficial soft tissues. It is now commonly accepted that Electromagnetic Fields (EMF) are capable of initiating various healing processes including delayed fractures, pain relief, multiple sclerosis, and Parkinson's disease. This proven benefit could be obtained by using both static and time-varying magnetic fields [15]. PEMF is used in the off-label application of healing chronic wounds, such as pressure sores, diabetic leg, and foot ulcers [16].

Pulsed Electromagnetic Fields (PEMF) modalities are usually applied directly on the targeted area of the body. Compared to regular pharmaceuticals, PEMF offers an alternative with fewer, if any, side effects. This is a tremendous advantage versus pharmaceutical treatment at which the administered medication spreads over the entire body, thereby causing adverse effects in different organs, which sometimes might be significant [16].
Aerobic exercise increases the release of several neurotransmitters including natural endorphins (the brain natural painkillers), estrogen, progesterone, dopamine and endogenous opiate peptides, as well as altering the reproduction of hormone secretion, suppressing prostaglandin from being released and raising the estrone-estradiol ratio which acts to decrease endometrial proliferation and shunts blood flow away from the uterus $[\mathbf{1 7 , 1 8}]$.

Aerobic exercise stimulates the release of endorphins that relieve pain by inhibiting the pain pathways [19]. It also makes the patient more active, reducing the fear of moving (kinesiophobia) and increasing self-confidence [20]. Lastly, these exercises increase muscle blood flow and may reduce the stiffness commonly observed in patients with low back pain [21].

\section{Subjects, Material and Methods}

\section{I- Subjects:}

Forty girls diagnosed with primary dysmenorrhea participated in this study. The study was conducted from September 2018 to May 2019. They were selected randomly from Kasre El-Ainy University Hospital in Cairo. They had regular menstrual cycle. Their ages were ranged from 1625 years. Their Body Mass Index (BMI) was ranged from $20-25 \mathrm{Kg} / \mathrm{m}^{2}$. All of them were virgins. Girls with irregular or infrequent menstrual cycles, pacemaker, hyperthyroidism, pelvic pathology and BMI $<25 \mathrm{Kg} / \mathrm{m}$ or $>20 \mathrm{Kg} / \mathrm{m}$ are excluded from the study. This study was performed under Ethical Committee No 012/002599. Faculty of Physical Therapy, Cairo University. Design of this study was two group pre-test and post-test experimental design. They were divided into two equal groups: Group A consisted of twenty girls and treated by pulsed electromagnetic field on the pelvic region, 3 times per week for four weeks. Group B consisted of twenty girls and treated by aerobic exercise, 3 times per week for four weeks.

\section{II-Material:}

1- Informed consent form.

2- Weight-height scale.

It was used to measure the weight and height of all girls in both groups (A \& B) before starting of the study to calculate their BMI.

3-Visual analogue scale: It was used, to assess pain of each patient in both groups (A \& B) before and after treatment.

4- Easy Qs portable magneto-therapy: It was used for treatment of group A only. EASY Qs is a 
practical and portable device, easy to use and particularly suitable for targeted treatment.

5- Electrical treadmill: It was used for performing aerobic exercise for patients of group B only.

6- The short form health survey (SF-12): It was used for assessment of quality of life for both groups (A \& B) before and after treatment.

7- Blood analysis: It was used to measure the level of progesterone for both groups A \& B before and after treatment.

\section{III- Procedures:}

All patients were given full explanation about the assessment and treatment procedures and informed consent form was signed from each girl before participating in the study.

\section{A- Evaluative procedures:}

1- Weight and height measurement: The weight and height of each patient were measured while the patient was wearing light clothes and bare feet, to calculate the body mass index before treatment for both groups A \& B according to the following equation [22].

2- Visual Analogue Scale (VAS): A graphic rating scale with numerical values placed equidistantly along the line. The descriptors and numbers helped the participant to place her estimate on line in which 0 mean no pain, 1 mean mild pain, 2 mean moderate pain, 3 mean sever pain, 4 mean very severe pain and 5 mean unbearable pain. Each participant was asked to read over the list of adjectives and select the word that best describes her pain on the scale [23]. It was used, to assess pain of each patient in both groups (A \& B) in first day of menstrual cycle (before treatment) and in first day of next menstrual cycle (after treatment).

3- Short form health survey (SF-12): The SF-12 survey contains categorical questions (e.g., yes/ no) that assess limitations in role functioning as a result of physical and emotional health. The survey also contains Likert response formats including those that are on a three-point scale (e.g., limited a lot, limited a little, or not limited at all) that assess limitations in physical activity and physical role functioning. In addition a fivepoint scale (e.g., not at all, a little bit, moderately, quite a bit, and extremely) that assesses pain, and a five-point scale that assesses overall health (excellent, very good, good, fair, and poor) are included. The SF-12 also contains a six-point scale (e.g., all of the time, most of the time, a good bit of the time, some of the time, a little of the time, and none of the time) that assesses mental health, vitality, and social functioning. It was used for assessment of quality of life for both groups (A \& B) before and after treatment.

The higher score indicating less dysfunction, impairment, or pain consistent with recommended procedures for scoring [24].

4- Blood analysis: A blood sample was taken from each girl in both groups (A and B) before and after treatment to estimate the plasma level of progesterone and was sent to laboratory center used to measure the progesterone level in the blood. Each participant was asked to lie in half lying position, with well supported back and arms. The anticubital area was cleaned with alcohol. Blood sample of about $2 \mathrm{ml}$ was drawn from the anticubital vein by disposable sterile syringe. Blood samples were drawn and transferred to precooled EDTA tube. It was immediately centrifuged within $2500 \mathrm{rpm} / 10 \mathrm{~min}$. Plasma was drawn with micropipette and kept at $-80 \mathrm{C}$ until the time of analysis. Progesterone level was assessed at the day 21 of the menstrual cycle. The basal venous blood samples were obtained from all the patients in the morning between 9.00a.m. and 11.00a.m. [25].

Samples were run in the same assay to reduce any variance from inter-assay variability. The samples were taken in the luteal phase of the menstrual cycle at the day 21 of menstrual cycle before and after the treatment course.

\section{B- Treatment procedures:}

\section{1- Pulsed electromagnetic field therapy for group}

$A$ : Before starting the treatment sessions, each patient in group A was informed about the benefits of PEMF to gain her motivation and cooperation during the treatment course.

\section{Power supply: 100-240V 50-60Hz 300 VA [26].}

First, each patient of group (A) was asked to evacuate her bladder to be more relaxed, then she was advised to relax in side lying position. After that, one electrode was applied above supra pubic region and the other on lumber region Fig. (1). Both electrodes were fixed by long strap and the apparatus was switched on and adjusted to produce frequency of $50 \mathrm{HZ}$ and intensity of 60 gausses. It was applied for 15-25 minute 3 days per week for 4 weeks.

2- Aerobic exercise for group B: Before starting the treatment sessions, each patient in group B was informed about the benefits of the aerobic exercise to gain her motivation and cooperation 
during the treatment course. She was advised to drink plenty of fluids before and after the exercise session and wear supportive, wellfitting running or walking shoes.

The treadmill exercise program consisted of:

A- Warm up phase: Warm up phase in which each girl walked at $80 \mathrm{~m} / \mathrm{min}$ at $0.0 \%$ grade for $5 \mathrm{~min}$.

$B$ - Active phase: Treadmill speed was increased to $147 \mathrm{~m} / \mathrm{min}$ and grade was increased gradually until reached $25 \%$ grade for $20 \mathrm{~min}$.

C- Cool down phase: Cool down period in which the treadmill speed and grade will be decreased to $2.0 \mathrm{miles} / \mathrm{h}$ and $0.0 \%$ grade during a cool down period Fig. (2).

The exercise was repeated three times a week for four week [27].

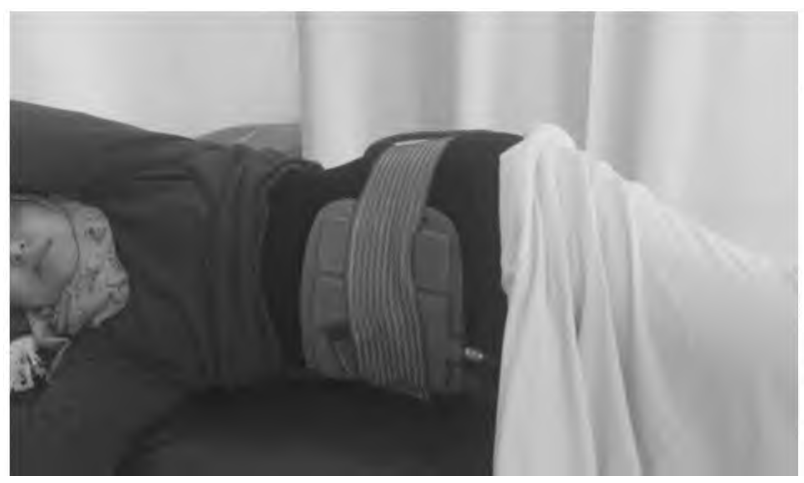

Fig. (1): Pulsed electromagnetic field.

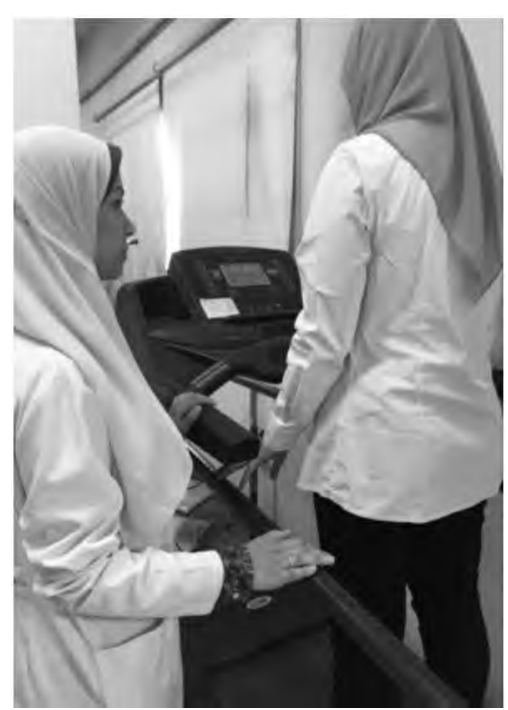

Fig. (2): Aerobic exercise in form of treadmill.

\section{Statistical analysis:}

Statistical analysis was conducted using SPSS for windows, version 22 (SPSS, Inc., Chicago, IL). The current test involved two independent variables. The first one was the (tested group); between subjects factor which had two levels (group A received pulsed electromagnetic field and group $\mathrm{B}$ received aerobic exercise). The second one was the (measuring periods); within subject factor which had two levels (pre-treatment, post-treatment). In addition, this test involved three tested dependent variables (progesterone hormone, SF12 and VAS). Prior to final analysis, data were screened for normality assumption, homogeneity of variance, and presence of extreme scores. This exploration was done as a pre-requisite for parametric calculations of the analysis of difference. Progesterone hormone, SF12 and VAS were normally distributed, as assessed by Shapiro-Wilk's test ( $p>.05)$. There was homogeneity of variances, as assessed by Levene's ( $p>.05)$ for almost dependent variables (progesterone hormone, SF12 and VAS). Accordingly, 2 X 2 Mixed MANOVA test was used to compare the tested variables of interest at different measuring periods at both groups. With the initial alpha level set at 0.05 .

\section{Results}

\section{I- General characteristics of the patients:}

There were no significant differences $(p>0.05)$ in the mean values of age and BMI between both groups (A and B) (Table 1).

\section{II- 2 X 2 mixed design MANOVA:}

\section{A- Overall effect:}

Statistical analysis using 2 X 2 mixed design MANOVA indicated that there were significant effects of the tested group (the first independent variable) on the all tested dependent variables; progesterone hormone, SF12 and VAS $(\mathrm{F}=19.832$, $\left.p=0.0001^{*}\right)$. As well as, there were significant effects of the measuring periods (the second independent variable) on the tested dependent variables $(\mathrm{F}=93.484, p=0.0001 *)$. Additionally, the interaction between the two independent variables was significant, which indicates that the effect of the tested group (first independent variable) on the dependant variables was influenced by the measuring periods (second independent variable) $(\mathrm{F}=$ 27.257, $p=0.0001 *)$ (Table 2).

\section{II- Multiple pairwise comparison tests (Post hoc tests):}

A- Within groups:

In group A, there was significant decrease in VAS and significant increase in progesterone hormone and quality of life. In group B, there was significant decrease in VAS and significant increase in quality of life and no significant increase in progesterone hormone (Table 3), Figs. (3-5). 
Table (1): Physical characteristics of patients in both groups (A \& B).

\begin{tabular}{|c|c|c|c|c|c|}
\hline \multirow{2}{*}{ Items } & \multirow{2}{*}{$\begin{array}{c}\text { Group A } \\
\text { Mean } \pm \text { SD }\end{array}$} & \multirow{2}{*}{$\begin{array}{c}\text { Group B } \\
\text { Mean } \pm \text { SD }\end{array}$} & \multicolumn{2}{|c|}{ Comparison } & \multirow{2}{*}{$\mathrm{S}$} \\
\hline & & & $t$-value & $p$-value & \\
\hline Age (years) & $22.45 \pm 2.21$ & $21.1 \pm 2.19$ & 1.936 & 0.06 & NS \\
\hline BMI $\left(\mathrm{kg} / \mathrm{m}^{2}\right)$ & $23.56 \pm 1.54$ & $23.58 \pm 1.51$ & -0.033 & 0.974 & NS \\
\hline
\end{tabular}

Table (2): The 2 X 2 mixed design multivariate analysis of variance (MANOVA) for all dependent variables at different measuring periods between both groups.

\begin{tabular}{lcl}
\hline Source of variation & F-value & $p$-value \\
\hline Groups & 19.832 & $0.0001^{*}$ \\
Measuring periods & 93.484 & $0.0001^{*}$ \\
Interaction & 27.257 & $0.0001^{*}$ \\
\hline
\end{tabular}

*: Significant at alpha level $<0.05$.

Table (3): Results of all dependent variables between tested groups $\mathrm{A}$ and $\mathrm{B}$.

\begin{tabular}{|c|c|c|c|c|c|}
\hline $\begin{array}{l}\text { Dependent } \\
\text { variables }\end{array}$ & $\begin{array}{l}\text { Pre- } \\
\text { treatment }\end{array}$ & $\begin{array}{l}\text { Post- } \\
\text { treatment }\end{array}$ & $\begin{array}{l}\text { Mean } \\
\text { difference }\end{array}$ & $\begin{array}{c}\% \text { of } \\
\text { change }\end{array}$ & $\begin{array}{c}\text { Within } \\
\text { group } \\
p^{-} \\
\text {value }\end{array}$ \\
\hline \multicolumn{6}{|l|}{ Progesterone: } \\
\hline Group (A) & $6.93 \pm 2.79$ & $10.91 \pm 3.2$ & -3.98 & $57.43 \%$ & $0.0001 *$ \\
\hline Group (B) & $7.93 \pm 4.1$ & $8.14 \pm 3.78$ & -0.21 & $2.6 \%$ & 0.652 \\
\hline$p$-value* & 0.381 & $0.019 *$ & & & \\
\hline \multicolumn{6}{|l|}{ Quality of life: } \\
\hline Group (A) & $26.94 \pm 2.22$ & $32.21 \pm 3.73$ & -5.27 & $19.56 \%$ & $0.0001 *$ \\
\hline Group (B) & $26.2 \pm 1.39$ & $27.4 \pm 1.39$ & -1.2 & $4.5 \%$ & $0.014^{*}$ \\
\hline$p$-value* & 0.214 & $0.0001 *$ & & & \\
\hline \multicolumn{6}{|c|}{$\begin{array}{l}\text { Visual analogue } \\
\text { scale: }\end{array}$} \\
\hline Group (A) & $4.1 \pm 0.73$ & $1.47 \pm 0.77$ & 2.63 & $64.14 \%$ & $0.0001 *$ \\
\hline Group (B) & $3.95 \pm 0.88$ & $3.3 \pm 0.65$ & 0.65 & $16.45 \%$ & $0.0001^{*}$ \\
\hline$p$-value* & 0.557 & $0.0001 *$ & & & \\
\hline
\end{tabular}

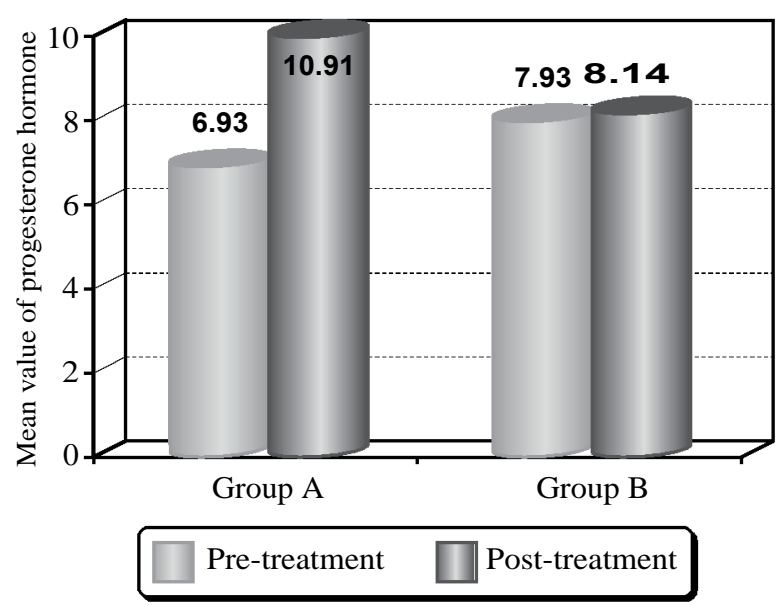

Fig. (3): Mean values of progesterone hormone pre and posttests in both groups.

\section{B-Between groups:}

Pre-treatment, there was no significant difference between both groups (A and B) in progesterone hormone, VAS and quality of life. While post-treatment, there was significant difference between both groups (A and $\mathrm{B}$ ) in progesterone hormone (more increase in group A), VAS (more decrease in group A) and quality of life (more increase in group A) (Table 3), Figs. (3-5).

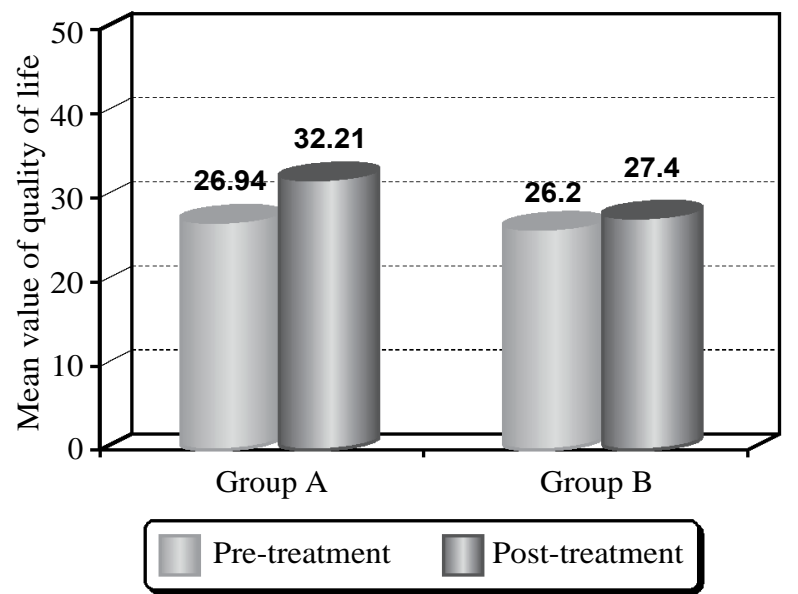

Fig. (4): Mean values of quality of life pre and post-tests in both groups.

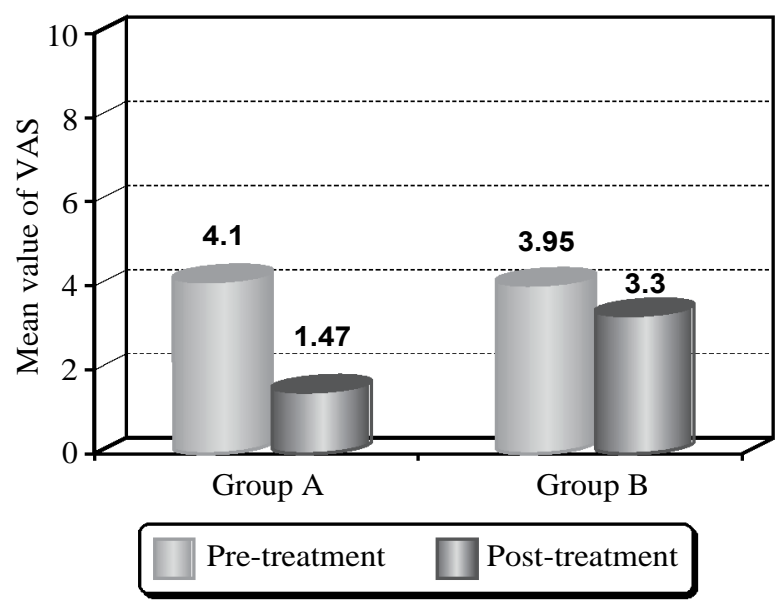

Fig. (5): Mean values of VAS pre and post-tests in both groups.

\section{Discussion}

Dysmenorrhea is the most common gynecological complaint among adolescent and young adult females with a major impact on women's quality of life, work productivity, and health-care utilization [1]. Primary dysmenorrhea is associated with normal ovulatory cycles and with no pelvic pathology. Primary dysmenorrhea is a painful menstrual cramp without any evident pathology to account for them, and it occurs in up to $50 \%$ of menstruating females and causes significant disruption in quality of life and absenteeism [6]. 
Clinical research has identified a physiological reason for dysmenorrhea is the production of uterine prostaglandins. During endometrium sloughing endometrial cells release prostaglandins as menstruation begins. Prostaglandins stimulate myometrium contractions and ischemia [9]. It was reported that progesterone inhibits prostaglandin synthesis and therefore decreases myometrium contractility [28].

Although analgesics, oral contraceptive pills and NSAIDs are common treatments for primary dysmenorrhea, about $20-25 \%$ of cases are not improved [29].

Today, magneto-therapy provides a non-invasive, safe and easy method to directly treat the site of injury, the source of pain and inflammation, and a variety of diseases and pathologies $[13,30]$. Pulsed electromagnetic fields exhibits the following activities for decreasing pain, including: Selective attenuation of neuronal depolarization by altering membrane resting potential, increasing blood flow potentially accelerating tissue healing and removing noxious mediators, altering ion binding kinetics and therefore modulating release of cytokines and other inflammatory mediators [31].

This study was conducted to compare between the effect of pulsed electromagnetic field and aerobic exercise on primary dysmenorrhea. Forty girls diagnosed with primary dysmenorrhea participated in this study. They were selected randomly from Kasre El-Ainy University Hospital in Cairo. They had regular menstrual cycle. Their ages were ranged from 16-25 years. Their Body Mass Index (BMI) was ranged from $20-25 \mathrm{Kg} / \mathrm{m}$. All of them were virgins.

They were divided into two equal groups: Group A consisted of twenty girls and treated by pulsed electromagnetic field on the pelvic region, 3 times per week for four weeks. Group B consisted of twenty girls and treated by aerobic exercise, 3 times per week for four weeks. Pain was evaluated by VAS, quality of life was assessed by short form health survey (SF-12) and progesterone hormone was evaluated for both groups (A and B) before and after treatment.

Results found that, within groups; in group A, there was significant decrease in VAS and significant increase in progesterone hormone and quality of life. In group B, there was significant decrease in VAS and significant increase in quality of life and no significant increase in progesterone hormone. Between groups; pre-treatment, there was no significant difference between both groups (A and B) in progesterone hormone, VAS and quality of life. While post-treatment, there was significant difference between both groups (A and B) in progesterone hormone (more increase in group $\mathrm{A}$ ), VAS (more decrease in group A) and quality of life (more increase in group A).

The results of this study revealed significant decrease in pain intensity in-group (A) who was treated by pulsed electromagnetic current, this come in agreement with [32] who studied the effect of Pulsed Electromagnetic Field (PEMF) in treatment of primary dysmenorrhea. They proved that, there was highly statistically significant decrease in menstrual pain intensity, highly statistically significant decrease in prostaglandin level in blood and improvement in physical and psychological symptoms that associated with dysmenorrhea, after treatment program. Therefore, PEMF is effective in relieving pain of dysmenorrhea by increasing progesterone therefore decrease prostaglandin and uterine menstrual pain.

The results of this study also agreed with [33] who studied the effectiveness of Pulsed Electromagnetic Therapy (PEMT) in patients with chronic lower back pain. PEMT produced significant pain reduction throughout the observation period compared with baseline values. The mean revised Oswestry disability percentage after 4 weeks was significantly improved from the baseline value in the PEMT group, whereas there were no significant differences in the placebo group. In conclusion, PEMT reduced pain and disability and appears to be a potentially useful therapeutic tool for the conservative management of chronic lower back pain.

The results of this study also agreed with [34] who studied the efficacy of extracorporeal magnetic stimulation for treatment of chronic prostatitis/ chronic pelvic pain syndrome in patients who do not respond to pharmacotherapy. The study revealed that, electromagnetic stimulation offers a new treatment option for patients with CP/CPPS who do not respond to pharmacotherapy.

The results of this study also agreed with [35] who reported that, PEMF is effective to reduce formalin induced chronic pain in mice at both acute and chronic phases and the most effective responses were obtained at $50 \mathrm{HZ}$ frequency. So, PEMF is effective in decreasing the pain at $50 \mathrm{~Hz}$ frequency.

The results of this study supported by [36] who carried a study upon 28 females with Fibromyalgia (FM) (22 to 50 years of age) treated using pulsed magnetic fields of very low intensity and very low 
frequency. They reported that, there was high statistically significant improvement in the pain thresholds, ability to perform daily activities and sleep quality. So, very low-intensity magnetic stimulation represents safe and effective treatment for chronic pain and other symptoms associated with fibromyalgia.

The results of the current study also supported by [37] who studied the effect of pulsed electromagnetic therapy in treatment of back pain. There was reduction in pain as assessed with Numeric Pain Rating Scale (NPRS), improvement in functional ability status as assessed with Functional Activity Scale (FAS). Also, there was a statistically significant faster pain relief and resumption of active functions in patients treated with PEMF plus analgesic compared with the rates exhibited by patients treated with standard analgesics alone. So, PEMF therapy is beneficial in reducing pain and disability in patients with low back pain.

Although the mechanism by which PEMT reduces pain is unclear, several explanations have been put forward to explain its analgesic effect, including the stimulation of descending inhibition and a subsequent increase in central $\beta$-endorphin production, hyperpolarization at the motor end plate and subsequent muscle relaxation and the stimulation of chondrogenesis. The promotion of increased blood flow to tissues and the modulation of the release of cytokines or other factors have also been suggested. Any of these proposed mechanisms could be responsible for the results of the present study since lower back pain has a complex nature and originates from multiple sources, including musculoskeletal structures and spinal nerves [33].

$[38,39]$ stated that PEMF treatment stimulate the expression of cytokines and metabolic pathways involved in dampening and resolving the inflammatory response and increase in endogenously expressed opioid precursors, both at the messenger (m) RNA and peptide levels resulting in decrease pain and inflammation.

The results of the current study also supported by [40] who studied the effect of pulsed electromagnetic field therapy on knee osteoarthritis and revealed that, after two weeks of PEMF exposure (30 minutes, 5 days per weeks), there was high statistically significant improvement in pain and functional scores at the end of treatment.

The results of the current study are consistent with that of [41] who stated that, low-frequency PEMF therapy improve function, pain, fatigue, and global status in fibromyalgia (FM patients). PEMF was effective in decreasing pain and associated symptoms that not recurrent as other therapy intervention.

The results of the current study are also come in consistency with that of [42] who studied the effect of pulsed electromagnetic fields on postoperative pain in forty-two females undergoing breast augmentation. Pulsed electromagnetic field therapy provides pain control with a noninvasive modality and reduced morbidity.

The results of this study revealed significant increase in progesterone level in group (A) who was treated by PEMF, this was supported by [43] who studied the influence of sinusoidal $50-\mathrm{HZ}$ magnetic field on cultured human ovarian granulosa cells. They stated that, there was significant increase in $\mathrm{P}$ production by granulosa cells recorded in $32 \%$ of patients who exposed to magnetic field. Concordantly, the PEMF has positive effect on progesterone and is effective in decreasing the menstrual pain by increasing opioid precursors and increasing progesterone lead to production of less prostaglandin and less leukotriene and cytokines which have accounted for the reduction of menstrual pain and symptoms.

The result of this study disagreed with [44] who studied the effect of $50 \mathrm{~Hz}$ magnetic field on sex hormones of adult female rats exposed to a $50 \mathrm{~Hz}$ sinusoidal magnetic field at approximately 25 microT ( 0.25 Gauss) for 18 weeks. Serum level progesterone was measured before, after, and during the exposure. At the end of the study there was significantly decreased in progesterone level after 18 weeks of exposure $(p<0.05)$.

The results of this study also disagreed with those of [45] who reported that PEMF does not directly influence pain perception in healthy individuals. This study was conducted to determine whether the analgesic effect observed in patients are attributable to a direct effect of PEMF on pain or to an indirect effect of PEMF on inflammation and healing. When compared to baseline, there was no change in pain intensity and unpleasantness following the application of real or sham PEMF. This may be explained by the methodological and clinical heterogeneity, making comparisons difficult. Studies differ in terms of device technology, physical parameters, treatment duration and frequency, outcome measures and study periods.

Also, the results of this study disagreed with those of [46] who studied the effect of pulsed electromagnetic fields in the treatment of knee 
osteoarthritis. They stated that PEMF provides no significant additional benefit to physiotherapy in relieving pain in cases of knee osteoarthritis. This study was carried out for five sessions upon two weeks only.

Results of this study also disagreed with [47] who studied the effects of 50-Hz sinusoidal Magnetic Fields (MFs) on embryo implantation and progesterone during the pre-implantation and implantation periods in rats. MFs did not influence the mean total number of implantations and serum progesterone level did not significantly change.

The results of this study revealed significant decrease in pain in group (B) who treated with aerobic exercise. This comes in agreement with [48] who proved that exercise is an effective treatment for primary dysmenorrhea.

Exercises enhance release of endorphins, relaxation, stress relief and improved blood flow can reduce the severity and duration of dysmenorrhea [49].

Results of this study agreed with [50] who examined the effect of aerobic exercise on some menstrual symptoms of nonathletic students, and concluded that regular and continuous aerobic exercises can control initial dysmenorrhea and severe menstrual bleeding.

Results of this study also agreed with [51] who examined the effect of 8 weeks of isometric exercises on primary dysmenorrhea in female students, and concluded that performing isometric exercises (including abdominal, pelvic and groin enhancement exercises) is effective in reducing the severity and duration of pain and the rate of use of medication in females suffer from dysmenorrhea.

Dysmenorrhea is less prevalent in athletes who had begun their sports activities prior to menarche, and that there was improvement in symptoms after initiation of exercise, and athletes participating in more intense sports activities had less severe menstrual symptoms [52].

Results of this study supported by [53] who showed that the severity of primary dysmenorrhea decreased at the end of 8 weeks of aerobic exercise.

Results of this study also supported by [52] who found that, aerobic exercise increase the release of endorphins by the brain, which can raise the pain threshold. The increase in uterine blood flow and metabolism in aerobic activities can be effective against dysmenorrhea. The aerobic training took pain to faster transfer of waste and prostaglandin the womb helps reduce the pain of dysmenorrhea.

Results of this study come in consistent with [54] who suggested a program of exercise for dysmenorrhea patient 2-3 times a day before the period. They reported that exercise reduces pain during menstruation by relaxing abdominal muscles and relieves pressure on the nerve centers, pelvic organs and decrease pelvic congestion.

Results of this study also come in consistent with $[\mathbf{5 5 , 5 6 ]}$ who stated that, aerobic exercises are beneficial in primary dysmenorrhea and improve quality of life. Aerobic exercise is found to be effective in reducing pain and symptoms of dysmenorrhea. It is considered that the pain during menstrual cycle is due to prostaglandins' which are present in high quantities in menstrual fluid.

Results of this study also come in consistent with $[\mathbf{5 7 , 5 8}]$ who suggested that, low intensity exercise (walking, jogging at $40-50 \%$ of maximal heart rate), while others argue that moderately intensive exercise (50-60\% of maximum heart rate) is better, and yet others argue that high intensity activity (70-75\% of maximum heart rate) is most beneficial for primary dysmenorrhea.

The results of this study disagreed with [59] who proved that there was no significant relationship between the incidence of dysmenorrhea between athletic and non-athlete groups [58]. Added that there was no relationship between the level of physical activity and the severity of dysmenorrhea.

To our knowledge there is no previous studies compare between the effect of pulsed electromagnetic field and aerobic exercise on primary dysmenorrhea. So, this is the first study which makes this comparison.

\section{Conclusion:}

It can be concluded that pulsed electromagnetic field is more effective than aerobic exercise in treating primary dysmenorrhea.

\section{Acknowledgements:}

Authors appreciate and thanks all patients participated in this study.

\section{References}

1- HAREL Z.: Dysmenorrhea in adolescents. Annals of the New York Academy of Sciences, 1135 (1): 185-95, 2008.

2- KUMAR K.H. and ELAVARASI P.: Definition of pain and classification of pain disorders. Journal of Advanced Clinical and Research Insights, 3 (3): 87-90, 2016. 
3- ROSNER J. and SARAO M.S.: Physiology, Female Reproduction. In StatPearls [Internet]. Stat. Pearls Publishing, 2019.

4- De ZIEGLER D., PIRTEA P., GALLIANO D., CICINELLI E. and MELDRUM D.: Optimal uterine anatomy and physiology necessary for normal implantation and placentation. Fertility and Sterility, 105 (4): 844-54, 2016.

5- ADEYEMI A.S. and ADEKANLE D.A.: Management of dysmenorrhoea among medical students. Int. J. Gynecol. Obstet., 7 (1): 39-43, 2007.

6- DAWOOD M.Y.: Primary dysmenorrhea: Advances in pathogenesis and management. Obstetrics \& Gynecology, 108 (2): 428-41, 2006.

7- O'CONNELL K., DAVIS A.R. and WESTHOFF C.: Selftreatment patterns among adolescent girls with dysmenorrhea. Journal of Pediatric and Adolescent Gynecology, 19 (4): 285-9, 2006.

8- IACOVIDES S., AVIDON I., BENTLEY A. and BAKER F.C.: Reduced quality of life when experiencing menstrual pain in women with primary dysmenorrhea. Acta Obstetricia et Gynecologica Scandinavica, 93 (2): 213-7, 2014.

9- PROCTOR M. and FARQUHAR C.: Diagnosis and management of dysmenorrhoea. BMJ, 332 (7550): 1134-8, 2006.

10- ARAÚJO L.M., De SILVA J.M.N., Da BASTOS W.T. and VENTURA P.L.: Pain improvement in women with primary dysmenorrhea treated by Pilates: Revista Dor, 13 (2): 119-23, 2012.

11- HARADA T.: Dysmenorrhea and endometriosis in young women. Yonago Acta Medica, 56 (4): 81, 2013.

12- GRANDI G., NAPOLITANO A., XHOLLI A., TIRELLI A., DiCARLO C. and CAGNACCI A.: Effect of oral contraceptives containing estradiol and nomegestrol acetate or ethinyl-estradiol and chlormadinone acetate on primary dysmenorrhea. Gynecological Endocrinology, 31 (10): 774-8, 2015.

13- MARKOV M.S.: Expanding use of pulsed electromagnetic field therapies. Electromagnetic Biology and Medicine, 26 (3): 257-74, $2007 \mathrm{a}$.

14- MARKOV M.S.: Pulsed electromagnetic field therapy history, state of the art and future. The Environmentalist, 27 (4): 465-75, 2007c.

15- HAZLEWOOD C.F., MARKOV M.S. and KOSTARAKIS P.: Magnetic fields for relief of myofascial and/or low back pain through trigger points. In Proceedings of Forth International Workshop Biological effects of electromagnetic fields, 475-83, 2006.

16- PILLA A.A.: Mechanisms and therapeutic applications of time-varying and static magnetic fields. Biological and Medical Aspects of Electromagnetic Fields, 3, 2007.

17- ONUR O., GUMUS I., DERBENT A., KAYGUSUZ I., SIMAVLI S., URUN E. and CAKIRBAY H.: Impact of home-based exercise on quality of life of women with primary dysmenorrhoea. South African Journal of Obstetrics and Gynaecology, 18 (1), 2012.

18- PRAMANIK T., SHRESTHA R., SHERPA M.T. and ADHIKARI P.: Incidence of dysmenorrhoea associated with high stress scores among the undergraduate Nepalese medical students. Journal of Institute of Medicine, 32 (3): 2-4, 2010.

19- STOPPLER M.C. and SHIEL W.C.: Endorphins: Natural pain and stress fighters. Medicine Net. Com., Available at: Http://Www. Medicine net. Com/Script/Main/Art. Asp, 2014.

20- WERTLI M.M., RASMUSSEN-BARR E., HELD U., WEISER S., BACHMANN L.M. and BRUNNER F.: Fearavoidance beliefs-a moderator of treatment efficacy in patients with low back pain: A systematic review. The Spine Journal, 14 (11): 2658-78, 2014.

21- DOS SANTOS I., LUNARDI A.C., De OLIVEIRA N. T.B., De ALMEIDA M.O. and COSTA L.O.P.: Effects of aerobic exercise on pain and disability in patients with non-specific chronic low back pain: A systematic review protocol. Systematic Reviews, 8 (1): 101, 2019.

22- COHEN L., MEIRA J., COSENDEY G.M., De SOUZA A.F.P., MATTOS F., CARNEIRO J.R.I. and ROSADO E.L.: Evaluation of the influence of whole and defatted flaxseed on satiety, glucose, and leptin levels of women in the late post-operative stage of bariatric surgery. Obesity Surgery, 23 (2): 157-66, 2013.

23- HARTRICK C.T., KOVAN J.P. and SHAPIRO S.: The numeric rating scale for clinical pain measurement: A ratio measure? Pain Practice, 3 (4): 310-6, 2003.

24- WARE Jr., J.E., KOSINSKI M. and KELLER S.D.: A 12Item Short-Form Health Survey: Construction of scales and preliminary tests of reliability and validity. Medical Care, 220-33, 1996.

25- MUNRO C.J., STABENFELDT G.H., CRAGUN J.R., ADDIEGO L.A., OVERSTREET J.W. and LASLEY B.L.: Relationship of serum estradiol and progesterone concentrations to the excretion profiles of their major urinary metabolites as measured by enzyme immunoassay and radioimmunoassay. Clinical Chemistry, 37 (6): 838-44, 1991.

26- EL-FATAH E.A. and SHAHEEN M.M.: Efficacy of Pulsed Electromagnetic Field in Treatment of Primary Dysmenorrhea, 2014.

27- KODESH E., KAFRI M., DAR G. and DICKSTEIN R.: Walking speed, unilateral leg loading, and step symmetry in young adults. Gait \& Posture, 35 (1): 66-9, 2012.

28- KUENZEL J., GEISLER K., MALTARIS T., MUELLER A., HOFFMANN I., SCHNEIDER H. and OPPELT P.G.: Effects of interactions between progesterone and prostaglandin on uterine contractility in a perfused swine uterus model. In Vivo, 28 (4): 467-75, 2014.

29- YU A.: Complementary and alternative treatments for primary dysmenorrhea in adolescents. The Nurse Practitioner, 39 (11): 1-12, 2014

30- MARKO M.S.: Magnetic field therapy: A review. Electromagnetic Biology and Medicine, 26 (1): 1-23, $2007 \mathrm{~b}$.

31- VADALÀ M., VALLELUNGA A., PALMIER L., PALMIERI B., MORALES-MEDINA J.C. and IANNITTI T.: Mechanisms and therapeutic applications of electromagnetic therapy in Parkinson's disease. Behavioral and Brain Functions, 11 (1): 26, 2015.

32- REFAYE E., EBRAHIM G., BOTLA A.M., HUSSEIN H.A.D., HAMADA H.A. and WADEE A.N.: Electromag- 
netic field versus diclofenac drugs on primary dysmenorrhea: A single-blind randomized controlled trial. Journal of Clinical and Analytical Medicine, 10 (2): 202-6, 2019.

33- BROWN C.S., LING F.W., WAN J.Y. and PILLA A.A.: Efficacy of static magnetic field therapy in chronic pelvic pain: A double-blind pilot study. American Journal of Obstetrics and Gynecology, 187 (6): 1581-7, 2002.

34- KIM T.H., HAN D.H., CHO W.J., LEE H.S., YOU H.W., PARK C.M. and LEE K.S.: The efficacy of extracorporeal magnetic stimulation for treatment of chronic prostatitis/chronic pelvic pain syndrome patients who do not respond to pharmacotherapy. Urology, 82 (4): 894-8, 2013.

35- JAHROMY M.H., JAFARI H., REZAEE S. and MOHAJER A.J.: Effects of extremely low frequency magnetic field (ELF-MF) on formalin induced chronic pain in mice. Pain Studies and Treatment, 4 (02): 13, 2016.

36- MAESTÚ C., BLANCO M., NEVADO A., ROMERO J., RODRÍGUEZ-RUBIO P., GALINDO J. and FERNÁNDEZ-ARGÜELLES P.: Reduction of pain thresholds in fibromyalgia after very low-intensity magnetic stimulation: A double-blinded, randomized placebo-controlled clinical trial. Pain Research and Management, 18 (6): 101-6, 2013.

37- OKE K.I. and UMEBESE P.F.A.: Evaluation of the efficacy of pulsed electromagnetic therapy in the treatment of back pain: A randomized controlled trial in a tertiary hospital in Nigeria. West Indian Medical Journal, 62 (3): 205-9, 2013.

38- MOFFETT J., GRIFFIN N.E., RITZ M.C. and GEORGE F.R.: Pulsed radio frequency energy field treatment of cells in culture results in increased expression of genes involved in the inflammation phase of lower extremity diabetic wound healing. The Journal of Diabetic Foot Complications, 2 (3): 57-64, 2010.

39- MOFFETT J., FRAY L.M. and KUBAT N.J.: Activation of endogenous opioid gene expression in human keratinocytes and fibroblasts by pulsed radiofrequency energy fields. Journal of Pain Research, 5: 347, 2012.

40- ÖZGÜÇLÜ E., ÇETIN A., ÇETIN M. and CALP E.: Additional effect of pulsed electromagnetic field therapy on knee osteoarthritis treatment: A randomized, placebocontrolled study. Clinical Rheumatology, 29 (8): 927-31, 2010.

41- SUTBEYAZ S.T., SEZER N., KOSEOGLU F. and KIBAR S.: Low-frequency pulsed electromagnetic field therapy in fibromyalgia: A randomized, double-blind, shamcontrolled clinical study. The Clinical Journal of Pain, 25 (8): 722-8, 2009.

42- HEDÉN P. and PILLA A.A.: Effects of pulsed electromagnetic fields on postoperative pain: A double-blind randomized pilot study in breast augmentation patients. Aesthetic Plastic Surgery, 32 (4): 660, 2008.

43- PAKSY K., THURÓCZY G., FORGÁCS Z., LÁZÁR P. and GAÁTI I.: Influence of sinusoidal 50-Hz magnetic field on cultured human ovarian granulosa cells. Electroand Magnetobiology, 19 (1): 91-7, 2000.

44- AL-AKHRAS M.A.: Influence of $50 \mathrm{~Hz}$ magnetic field on sex hormones and body, uterine, and ovarian weights of adult female rats. Electromagnetic Biology and Medicine, 27 (2): 155-63, 2008.
45- BEAULIEU K., BELAND P., PINARD M., HANDFIELD G., HANDFIELD N., GOFFAUX P. and LEONARD G.: Effect of pulsed electromagnetic field therapy on experimental pain: A double-blind, randomized study in healthy young adults. Electromagnetic Biology and Medicine, 35 (3): 237-44, 2016.

46- AY S. and EVCIK D.: The effects of pulsed electromagnetic fields in the treatment of knee osteoarthritis: A randomized, placebo-controlled trial. Rheumatology International, 29 (6): 663-6, 2009.

47- HUUSKONEN H., SAASTAMOINEN V., KOMULAINEN H., LAITINEN J. and JUUTILAINEN J.: Effects of low-frequency magnetic fields on implantation in rats. Reproductive Toxicology, 15 (1): 49-59, 2000.

48- DALEY A.J.: Exercise and primary dysmenorrhoea. Sports Medicine, 38 (8): 659-70, 2008.

49- CHANTLER I., MITCHELL D. and FULLER A.: Diclofenac potassium attenuates dysmenorrhea and restores exercise performance in women with primary dysmenorrhea. The Journal of Pain, 10 (2): 191-200, 2009.

50- MOHAMMADI B., AZAMIAN JAZI A. and FATHOLLAHI SHOURABEH F.: The effect of aerobic exercise training and detraining on some of the menstrual disorders in non-athlete students in Lorestan Universities. The Horizon of Medical Sciences, 18 (2): 5-12, 2012.

51- SHAVANDI N., TAGHIAN F. and SOLTANI V.: The effect of isometric exercise on primary dismenorrhea. Arak UNi. Med. Sci., 13 (1): 71-7, 2010.

52- ABBASPOUR Z., ROSTAMI M. and NAJJAR S.H.: The effect of exercise on primary dysmenorrhea. Journal of Research in Health Sciences, 6 (1): 26-31, 2006.

53- DEHNAVI Z.M., JAFARNEJAD F. and KAMALI Z.: The Effect of aerobic exercise on primary dysmenorrhea: A clinical trial study. Journal of Education and Health Promotion, 7, 2018.

54- SUTAR A., PALDHIKAR S. SHIKALGAR N. and GHODEY S.: Effect of aerobic exercises on primary dysmenorrhea in college students. J. Nurs. Health Sci., 5: 20-4, 2016.

55- GUMANGA S.K. and KWAME-ARYEE R.: Prevalence and severity of dysmenorrhoea among some adolescent girls in a secondary school in Accra, Ghana. Postgrad Med. J. Ghana, 1 (1): 1-6, 2012.

56- ESSIG D.A., ALDERSON N.L., FERGUSON M.A., BARTOLI W.P. and DURSTINE J.L.: Delayed effects of exercise on the plasma leptin concentration. Metabolism, 49 (3): 395-9, 2000.

57- KHONSARY S.A.: Guyton and Hall.Textbook of medical physiology. Textbook. Thirteenth ed. Elsevier Hardcover. Surgical Neurology International, 8, 2017.

58- DAVENEGHI S., TARIGHAT-ESFANJANI A. and DAHRI M.: Association of nutritional factors and physical activity with severity of primary dysmenorrheal pain. Journal of Health and Care, 18 (2): 93-100, 2016.

59- SEHATI F., HOMAEE M. and ZUDFEKR L.: Comparison of the prevalence of menstrual disorders (amenorrhea, oligomenorrhea, dysmenorrhea and premenstrual syndrome) female athlete and non-athlete students of Tabriz University. Journal of Obstetrics Gynecology and Infertility, 16 (51): 14-21, 2014. 


\section{تآثير الهجال الكهرومغناطيسى المتقطع مقابل التمرينات الهوائية

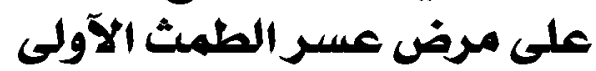

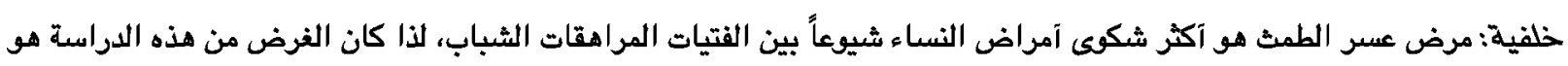

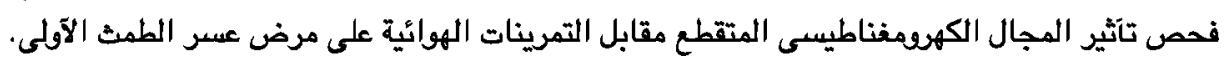

الهدف: آجريت هذه الدراسة للمقارنة بين تآثير المجال الكهومغناطيسى المتقطع والتمرينات الهوائية على مرض عسر الطمث الآولى. الآثخاص: شارك فى هذه الدراسة آريعون فتاة تم تشخيصهن على آنهن مصابات بمرض عشر الطمث الآولى. تم إختيارهن عشوائياً

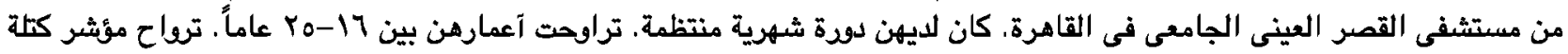

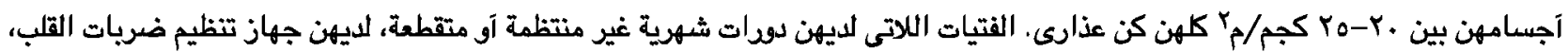

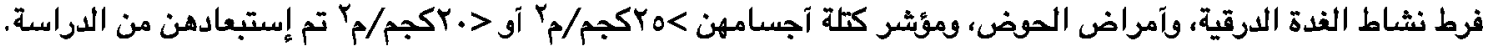

$$
\text { التصميم:كان تصميم هذه الدراسة تصميماً تجريياً (مجموعتين قبل وبعد الإختبار). }
$$

الطرق: تم تقسيمهن إلى مجموعتين متساويتين فى العدد: المجموعة (آ) تكونت من عشرين فتاة وتم علاجها بواسطة الججال الكهرومغناطيسى

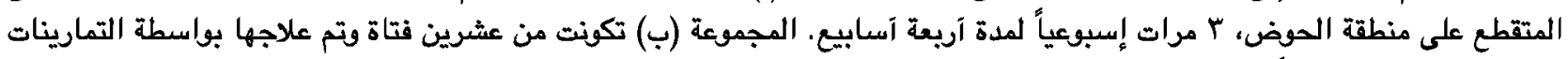
الهوائية، ب مرات إسبوعياً لمدة آربعة آسابيع.

التقييم: تم تقييم الآلم عن طريق المؤشر البصرى للآلم، تم تقييم جودة الحياة عن طريق الإستيان القصير وتم تقييم هرمون البروجسترون

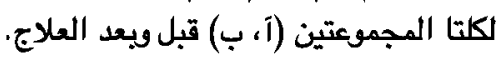

النتائج: آظهرت نتائج هذه الدراسة عدم وجود فرق ذو دلالة إحصائية بين المجموعتين (آ، ب) فى هرمون البروجستيرن، المؤشر البصرى

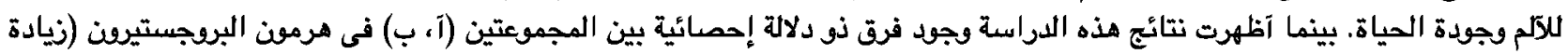

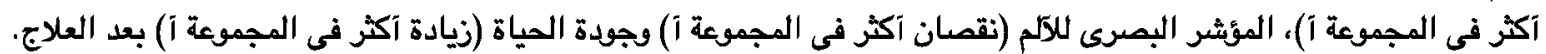
الخلاصة: مكذا يمكن آن نستخلص آن المجال الكهرومغناطيسى المتقطع آكثر فعالية من التمرينات الهوائية في علاج مرض عسر الطمث 